\title{
PENGARUH MANAJEMEN INOVASI PROGRAM PENDIDIKAN MA-BATUTER (MANAJEMEN APLIKASI BACA TULIS TERTINTEGRASI CERITA) PADA PENDIDIKAN ANAK USIA DINI (PAUD) TAAMASA SUMBAWA Aryayu Enny Wahyu ${ }^{1^{*}}$, Andy Tirta ${ }^{2}$, Shinta Esabella ${ }^{3}$
}

1,2,3 Program Studi Pasca Sarjana Universitas Teknologi Sumbawa

*Corresponding Author email: shinta.esabella@uts.ac.id, tirta78@gmail.com

\begin{tabular}{ll}
\hline \multirow{2}{*}{$\begin{array}{l}\text { Diterima } \\
\text { Bulan Juni 2020 }\end{array}$} & Pbstrak \\
\cline { 2 - 3 } & Penelitian bertujuan menguji perbedaan manajemen inovasi program pendidikan $M A-$ \\
& BATUTER (Manajemen Aplikasi Baca Tulis Tertintegrasi Cerita) pada anak didik dalam \\
& kondisi pengelolaan yang dilakukan sekolah secara konvensional dan secara digitalisasi. \\
& Metode penelitian yang digunakan adalah kualitatif experiment before-after yakni \\
membandingkan penilaian orangtua anak didik terkait pengelolaan program \\
Diterbitkan & pendidikan MA-BATUTER yang dilakukan secara konvensional dengan keadaan setelah \\
Bulan Juli 2020 & diimplementasikannya aplikasi secara digital yang dikembangkan secara mandiri oleh \\
& oleh PAUD TAAMASA Sumbawa. Data penelitian diperoleh dari 10 orang sampling \\
Keyword: & orangtua siswa dengan menggunakan instrumen penilaian berbasis skor pada aspek \\
Manajemen, & membaca, menulis, dan menceritakan kembali. Untuk menentukan efektifitas uji beda \\
Inovasi, & mengunakan statistik non parametrik melalui uji wilcoxon, uji gain score. Hasil \\
Pendidikan Anak, & penelitian uji-t dan gain score program pendidikan MA-BATUTER dengan aplikasi \\
Ma-Batuter & digital terbukti efektif meningkatkan kemampuan anak didik dalam memahami isi cerita \\
& serta dapat menceritakan kembali informasi yang diterimanya dalam rangka melatih \\
& sensor intelegensi anak sejak usia dini.
\end{tabular}

\section{PENDAHULUAN}

Masa anak-anak merupakan masa yang panjang dalam proses perkembangan dalam berbagai macam hal perkembangan seperti fisik, kognitif, mental, sosial, emosional, maupun perkembangan moral. Berbagai potensi anak yang ada pada masa tersebut penting untuk dioptimalkan dengan menyiapkan fasilitas dan wadah yang tepat baik di pendidikan formal di sekolah maupun pendidikan di keluarga.

Kehadiran Pendidikan Anak Usia Dini (PAUD) memberikan fasilitas untuk perkembangan potensi anak yang lebih optimal. PAUD merupakan cikal bakal pembentukan karakter bangsa (nation character building), sebagai titik awal dari pembentukan SDM berkualitas, yang memiliki wawasan, intelektual, kepribadian, tanggung jawab, inovatif, kreatif, proaktif, dan partisipatif serta semangat mandiri (Ridho, 2015: 60). Dengan demikian anak perlu didik agar mampu memahami berbagai hal, dan peran PAUD menjadi sangat penting dan strategis.

Sedemikian pentingnya peran dari PAUD sebagai salah satu sistem pendidikan nasional, maka pemerintah terus mendorong peningkatan penyelenggaraan PAUD dengan manajemen pengelolaan yang lebih baik dengan target tujuan adalah peningkatan potensi anak.

Namun pada kenyataannya, meskipun pemerintah dan masyarakat telah melakukan berbagai usaha untuk meningkatkan penyelenggaraan PAUD di Indonesia, PAUD di Indonesia masih menghadapi banyak persoalan kompleks dan saling terkait satu dengan yang lainnya. Persoalan tersebut antara lain, manajemen pengelolaan membaca, menulis dan bercerita yang saling terintegrasi kepada anak usia dini pada sebuah lembaga pendidikan

Menghadapi persoalan tersebut PAUD

TAAMASA telah menjalankan program manajemen baca tulis dan bercerita yang telah dilaksanakan selama 1 (satu) tahun terakhir. Mekanisme pelaksanaannya di masing-masing kelas tersedia perpustakaan kecil berisi buku cerita bergambar yang variatif, menarik, dan edukatif. Siswa pada setiap Jum'at, masing-masing anak diperbolehkan meminjam 1 (satu) buku untuk dibawa pulang, orang tua dihimbau untuk membacakannya di saat-saat santai bersama anak dengan tujuan untuk menumbuhkan kedekatan emosional antara orang tua dan anak, juga mampu mengenalkan literasi anak sejak dini. Mengukur pemahaman anak terhadap isi buku tersebut, orang tua diundang untuk menceritakannya kembali bersama anak di depan anak-anak lainnya.

Dalam kajian observasi yang peneliti lakukan terhadap program tersebut, ternyata belum maksimal dikarenakan pihak pengelola harus merasa kecewa saat pengembalian buku. Kondisi 
buku yang sudah tidak lagi seperti semula mulai dari sampul bukunya yang terpisah, halaman buku yang tercoret, beberapa bagian dalam yang tidak lagi utuh, bahkan buku yang tidak kembali dengan alasan hilang. Realita tersebut menjadikan pengelolah khawatir jika buku-buku yang lainnya akan bernasib sama, sementara untuk mengadakan buku bermutu serupa membutuhkan modal yang cukup besar.

Untuk meminimalisir resiko yang berkepanjangan dan untuk memudahkan akses peminjaman buku, maka salah satu inovasi yang dikembangkan PAUD TAAMASA adalah program pendidikan media digital dengan model $M A$ BATUTER (Manajemen Aplikasi Baca Tulis Terintegrasi Cerita). Aplikasi web yang dibangun dengan sistem digital ini menawarkan keterjaminan buku dalam keadaan aman dan kemudahan bagi orang tua dalam mendapatkan buku. Buku cerita bergambar yang menarik dan edukatif diunggah ke aplikasi. Masing-masing orang tua murid diberikan password untuk dapat mengaksesnya, dimana aplikasi dapat di akses melalui URL: www.ayumabatuter.com.

Setelah aplikasi diimplementasikan maka peneliti melakukan penilaian terhadap tiga indikator utama proses program pendidikan $M A$ BATUTER yaitu aspek membaca, menulis dan bercerita yang telah menggunakan aplikasi digital.

Penelitian ini menjadi penting untuk mengetahui perbedaaan penilaian orangtua peserta didik pada saat Ma-batuter dilaksanakan secara konvensional dan setelah program Ma-batuter dilaksanakan ssecara digital. Penelitian relevan dilakukan oleh Raodah \& Ali Subhan (2020: 17) menyatakan bahwa literasi media digital bagi guru PAUD Gugus Kenanga Kecamatan Dukuhseti Kabupaten Pati dapat memberikan dan meningkatkan pengetahuan, pemahaman, pengalaman serta keahlian para guru dalam menggunakan media digital untuk pembelajaran dan administrasi.

Berdasarkan hal tersebut maka tujuan penelitian ini adalah untuk menguji perbedaan manajemen inovasi program pendidikan $M A$ BATUTER (Manajemen Aplikasi Baca Tulis Tertintegrasi Cerita) pada anak didik dalam kondisi pengelolaan yang dilakukan sekolah secara konvensional dan secara digitalisasi di Taman Kanak-kanak Islam Terpadu TAAMASA (Taman Asuhan Anak Muslim dan Keluarga Samawa Cendekia) Sumbawa NTB.

\section{LANDASAN TEORI}

\section{Manajemen Inovasi}

Kreitner (2008: 54) mengemukakan konsep bahwa manajemen adalah proses penyelesaian masalah untuk mencapai tujuan organisasi secara efektif melalui penggunaan sumber daya secara efisien sesuai dengan perkembangan. Sedangkan menurut F. Taylor (2006: 16) menyatakan bahwa manajemen adalah seni mengetahui apa yang harus dilakukan, kapan harus dilakukan dan melihat bahwa itu bisa dilakukan dengan cara terbaik dan termurah. Dari beberapa pendapat para ahli di atas, dapat disimpulkan bahwa manajemen adalah upaya untuk mencapai sebuah tujuan (goal) dengan cara mengelola dan mengawasi dengan cara efektif dan efisien.

Mengupas manajemen inovasi tidak dapat dilepaskan dari pakar yang pertama kali memperkenalkan manajemen inovasi yaitu Josep Schumpeter (1934: 66) memberikan definisi bahwa inovasi merupakan kombinasi baru dari faktor-faktor produksi yang dibuat oleh pengusaha dan pemikiran inovasi adalah kekuatan pendorong yang penting (critical driving force) dalam pertumbuhan ekonomi. Konsep ini kemudian melahirkan berbagai produk inovasi baru salah satunya adalah manajemen inovasi pendidikan yang secara terus menerus melahirkan brbagai konsep baru mulai inivasi mikro hingga pada inovasi pada level makro. Kaitan dengan konsep inoivasi tersebut maka Ma-Batuter dapat dikatakan bahwa ma-batuter dalam versi digital merupakan salah salah satu produk dari manajemen inovasi.

\section{Program Pendidikan MA-BATUTER}

Pengembangan aplikasi ma-batuter berbasis web tidak dapat dilepaskan dari konsep digitalisasi pendidikan pada anak usia dini. Kemdikbud (2019: 12) dalam majalah digital "Jendela" edisi XXXIX bulan Oktober 2019 menyatakan bahwa perkembangan dunia digital begitu dinamis yang lambat laun bukan sekadar mempengaruhi tapi mengubah gaya hidup masyarakat tanpa dan sulit dihindari. Dengan demikian program digitalisasi sekolah harus didukung dan ditindaklanjuti dengan peningkatan kompetensi guru, khususnya di bidang penguasaan teknologi informasi dan komunikasi (TIK).

Untuk mencapai tujuan tersebut diperlukan suatu inovasi pembelajaran, yakni melalui digitalisasi sekolah. Diyakni bahwa dengan pembelajaran berbasis teknologi akan membuat tampilan dan gaya belajar lebih menarik dan terhindar dari rasa malas dan bosan untuk belajar. 
Pengembangan ma-batuter berbasis web merupakan salah satu upaya digitalisasi pada PAUD Tamaasa dengan maksud meningkatkan daya tarik pembelajaran dengan mengintegrasikan kemampuan membaca, menulis, dan bercerita dalam satu aplikasi yang bernama ma-batuter.

Batuter sendiri berasal dari bahasa Sumbawa yang berarti bercerita. Namun istilah dalam penelitian ini adalah akronim dari kata: baca tulis terintegrasi cerita. Membaca merupakan sebuah kegiatan meresepsi, menginterpretasi, serta menganalisa yang dilakukan oleh pembaca untuk mendapatkan pesan yang disampaikan oleh seorang penulis dalam media tulisan. Menulis adalah suatu kegiatan untuk menciptakan suatu catatan atau informasi pada suatu media dengan menggunakan aksara. Bercerita merupakan kegiatan berbahasa yang bersifat produktif, artinya dalam bercerita seseorang melibatkan pikiran, kesiapan mental, keberanian, perkataan yang jelas sehingga dapat dipahami oleh orang lain.

Dengan demikian maka konsep Batuter ini adalah membaca, menulis, dan bercerita yang terintegrasi dalam satu kegiatan seperti tampak pada gambar 1 .

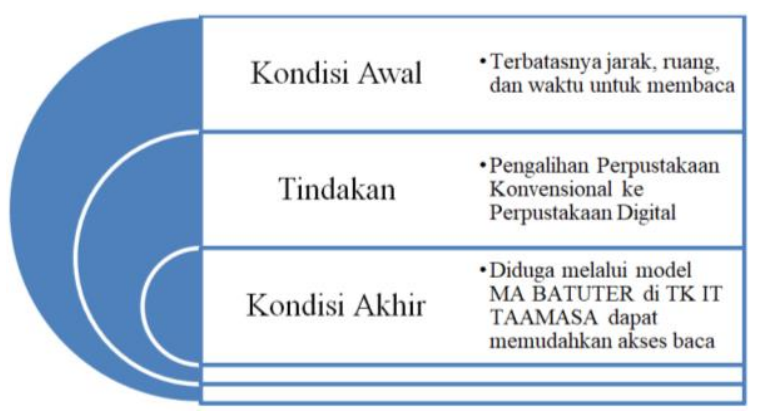

Gambar 1. Model MA-BATUTER

\section{METODE PENELITIAN}

Metode penelitian yang digunakan adalah kualitatif experimen before-after yakni membandingkan keadaan orang tua siswa terkait pengelolaan program pendidikan MA-BATUTER yang dilakukan secara konvensional dengan keadaan setelah diimplementasikannya aplikasi secara digital yang dikembangkan secara mandiri oleh oleh PAUD TAAMASA Sumbawa.

Penelitian ini dilakukan di Taman Kanakkanak Islam Terpadu TAAMASA (Taman Asuhan Anak Muslim dan Keluarga Samawa Cendekia) yang terletak di Karang Padak Desa Labuhan Sumbawa Kecamatan Labuhan Badas Kabupaten Sumbawa yang berjarak kurang lebih 50 meter dari Jembatan Samota, ikon Kota Sumbawa Besar.
Penelitian ini dijadwalkan dari pertengahan bulan Mei sampai dengan Agustus 2020.

Sumber data dan informasi diperoleh dari 10 orang tua murid TK IT TAAMASA, metode pengumpulan data penilaian (skoring) yang berisi pernyataan tertulis yang diisi orang tua siswa dan wawancara langsung dengan orang tua siswa. Teknik sampling yang digunakan adalah probability sampling dengan teknik yang diambil yaitu simple random sampling. Sugiyono (2013: 118), disebut simple random sampling karena pengambilan anggota sampel dari populasi dilakukan secara acak tanpa memperhatikan strata yang ada dalam populasi tersebut. Teknik ini dilakukan apabila anggota populasi dianggap homogen. Pemilihan sampel dengan menggunakan teknik simple random sampling adalah karena anggota populasi bersifat homogen, yakni seluruh orangtua siswa berhubungan dengan keuangan pengelolaan anak usia dini.

Menguji efektifitas pengaruh digunakan uji efektifitas model dengan menggunakan analisis statistik non parametrik melalui uji Wilcoxon dengan menggunakan rumus gain score (Hake, (1999: 2).

$$
\begin{aligned}
& \text { Rumus Gain score sebagai berikut. } \\
& \mathrm{g}=\% \text { Gain } / \% \text { Gain Max } \\
& \mathrm{g}=(\% \text { skor post test }-\% \text { skor pre-test }) / \\
& \quad(100 \%-\% \text { skor } \text { pre-test })
\end{aligned}
$$

\section{HASIL DAN PEMBAHASAN}

\section{Aplikasi MA-BATUTER}

\begin{tabular}{lcr}
\multicolumn{1}{c}{ Aplikasi } & MA-BATUTER & yang \\
dikembangkan dapat diakses di & laman \\
www.ayumabatuter.com dengan tampilan & seperti \\
gambar 2. &
\end{tabular}

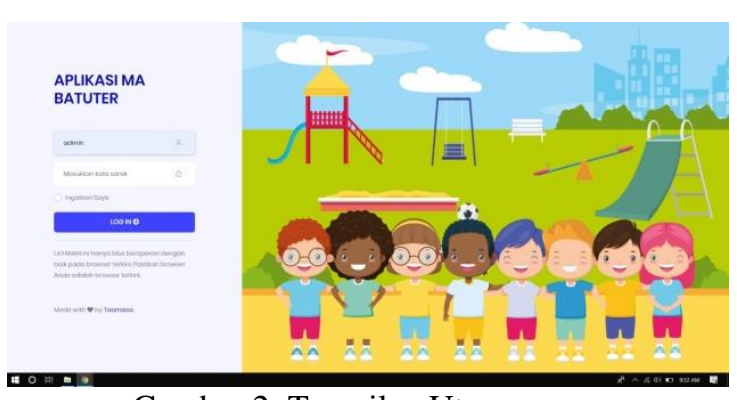

Gambar 2. Tampilan Utama

Pada menu utama terdapat beberapa menu tersedia untuk log in untuk admin, guru dan siswa. Pada kesempatan dan langkah pertama maka peneliti masuk dengan menu Admin untuk melengkapi setiap content yang tersedia di antaranya: Materi, galeri video, download file, dan master data. 


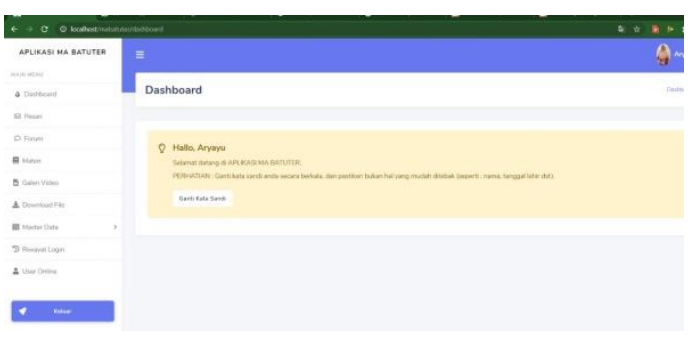

Gambar 3. Menu Utama MA-BATUTER

Pengisian menu content ini menjadi kunci utama keberhasilan program yang dikembangkan termasuk pilihan materi, tampilan, siswa dan orang tua akan mengakses setiap menu yang ditampilkan setelah login dengan password sendiri.

Keunggulan lain dari aplikasi ini adalah terdapat menu "pesan" yang dapat digunakan oleh guru dan siswa untuk saling berkomunikasi dengan sistem multi penerima (siswa) dalam sekali pengiriman pesan.

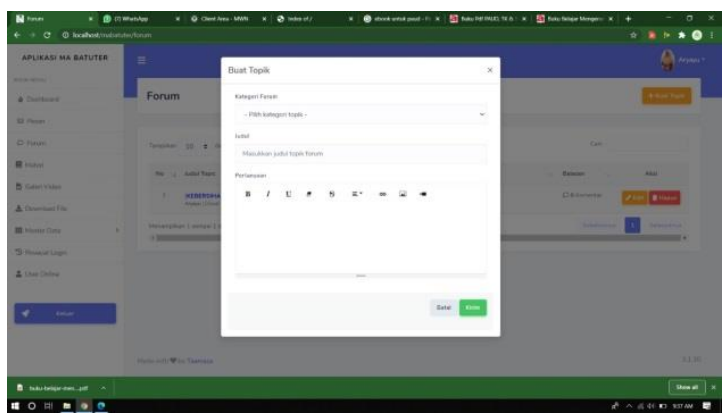

Gambar 4. Menu Pesan

Selanjutnya siswa yang bergabung di aplikasi ini dapat memperoleh materi yang telah diposting oleh admin sebelumnya. Kemudahan ini tentunya tidak dapat ditemui pada model konvensional. Pemilihan materi yang menarik berpengaruh terhadap daya tarik anak untuk terus mengakses aplikasi ini. Oleh karena update materi dilakukan secara berkala.

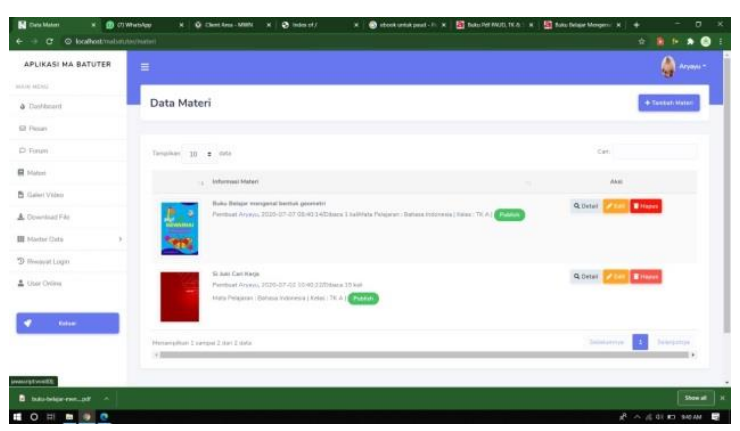

Pada tampilan aplikasi login untuk siswa dan guru tidak jauh berbeda dengan menu login Admin, perbedaan hanya terletak hak akses untuk edit dan input data termasuk menelusuri jejak untuk login pada aplikasi web MA-BATUTER.

\section{Efektifitas Model MA-BATUTER}

Data hasil kuesioner terhadap 10 orang tua siswa terhadap pengelolaan program pendidikan MA-BATUTER yang dilakukan secara digital dan konvensional dengan instrument rating scale, dimana berpedoman pada angka, yakni pada setiap angka memiliki nilai tertentu dengan kunci $4=$ sangat baik; 3 = di atas rata-rata; $2=$ di bawah rata-rata; 1= kurang (Sugiyono, 2013: 97). Kuesioner yang diajukan ke responden telah dilakukan uji validitas item pernyataan dengan menggunakan program SPSS 16.0 for windows. Sebuah kuisioner dinyatakan valid bila tidak ada soal yang memiliki nilai bertanda negatif dan lebih besar dari 0.05 (Azwar, 1999: 12).

Tabel 1. Perbandingan Konvensional dan Digital

\begin{tabular}{|c|l|c|c|}
\hline $\begin{array}{c}\text { No } \\
\text { Urut }\end{array}$ & Peserta & $\begin{array}{c}\text { Skor } \\
\text { Penilaian } \\
\text { secara } \\
\text { Konvensi } \\
\text { onal } \\
\text { (Pretest) }\end{array}$ & $\begin{array}{c}\text { Skor } \\
\text { Penilaian } \\
\text { secara } \\
\text { Digital } \\
\text { (Postest) }\end{array}$ \\
\hline 1. & Responden 1 & 26 & 36 \\
\hline 2. & Responden 2 & 27 & 39 \\
\hline 3. & Responden 3 & 26 & 38 \\
\hline 4. & Responden 4 & 26 & 36 \\
\hline 5. & Responden 5 & 28 & 39 \\
\hline 6. & Responden 6 & 27 & 39 \\
\hline 7. & Responden 7 & 26 & 37 \\
\hline 8. & Responden 8 & 27 & 38 \\
\hline 9. & Responden 9 & 29 & 39 \\
\hline 10. & Responden 10 & 25 & 39 \\
\hline \multicolumn{2}{|c|}{ Skor Maksimal } & 40 & 40 \\
\hline
\end{tabular}

Data tersebut selanjutnya dianalisis dengan uji-t berpasangan (paired samples t-test) untuk membandingkan selisih dua mean dari nilai pretest dan posttest dengan asumsi data terdistribusi normal. Hasil dari perhitungan dengan SPSS versi 16 diperoleh data seperti tabel 2.

Tabel 2. Descriptive Statistics

\begin{tabular}{|l|r|r|r|r|r|}
\hline & N & Mean & Std. Deviation & Minimum & Maximum \\
\hline PRETEST & 10 & 26.7000 & 1.15950 & 25.00 & 29.00 \\
POSTTEST & 10 & 38.5000 & 1.43372 & 36.00 & 40.00 \\
\hline
\end{tabular}

Gambar 5. Menu Materi. 


\section{Wilcoxon Signed Ranks Test}

Tabel 3. Wilcoxon Signed Ranks test

\begin{tabular}{|c|c|c|c|c|}
\hline \multicolumn{5}{|c|}{ Ranks } \\
\hline & & $\mathrm{N}$ & Mean Rank & Sum of Ranks \\
\hline \multirow[t]{4}{*}{ POSTEST - PRETEST } & Negative Ranks & $0^{3}$ & .00 & .00 \\
\hline & Positive Ranks & $10^{\circ}$ & 5.50 & 55.00 \\
\hline & Ties & $0 \circ$ & & \\
\hline & Total & 10 & & \\
\hline \multicolumn{5}{|l|}{ a. POSTEST < PRETEST } \\
\hline \multicolumn{5}{|l|}{ b. POSTEST > PRETEST } \\
\hline \multicolumn{5}{|l|}{ c. POSTEST = PRETEST } \\
\hline
\end{tabular}

Tabel 4. Test Statistics

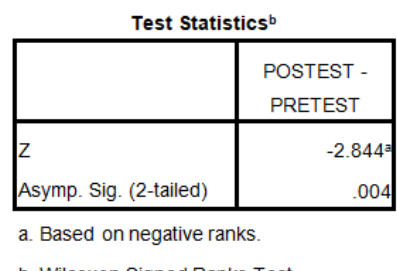

b. Wilcoxon Signed Ranks Test

Pada uji-t berpasangan jika taraf signifikan $<0,05$ maka menunjukkan ada hubungan antara variabel, sedangkan jika taraf signifikan > 0,05 maka tidak ada hubungan antar variabel. Berdasarkan tabel 4, terkait dengan Test Statistics ${ }^{b}$ di atas taraf signifikan sebesar 0,004 atau taraf signifikan $<0,05$ berarti ada pengaruh pengelolaan program pendidikan MA-BATUTER yang dilakukan dari model konvensional ke model digital.

Untuk menentukan efektifitas pengaruh pengaruh manajemen inovasi program pendidikan MA-BATUTER (Manajemen Aplikasi Baca Tulis Tertintegrasi Cerita) pada anak didik dalam kondisi pengelolaan yang dilakukan sekolah secara konvensional dan secara digitalisasi disajikan pada tabel 5 .

Tabel 5. Hasil penilaian tingkat efektivitas penerapan digital MA-BATUTER

\begin{tabular}{|c|c|c|c|c|c|c|}
\hline No & $\begin{array}{c}\text { Peser } \\
\text { ta }\end{array}$ & $\begin{array}{c}\text { Skor } \\
\text { Penilai } \\
\text { an } \\
\text { secara } \\
\text { Konve } \\
\text { nsional } \\
\text { (Pretest } \\
\text { ) }\end{array}$ & $\begin{array}{c}\text { Skor } \\
\text { Penil } \\
\text { aian } \\
\text { secar } \\
\text { a } \\
\text { Digit } \\
\text { al } \\
\text { (Post } \\
\text { test) }\end{array}$ & $\begin{array}{c}\text { Juml } \\
\text { ah } \\
\text { beda } \\
\text { prete } \\
\text { st } \\
\text { dan } \\
\text { postt } \\
\text { est }\end{array}$ & $\begin{array}{c}G a \\
\text { in } \\
S c \\
\text { or } \\
e\end{array}$ & $\begin{array}{c}\text { Kriteria } \\
\text { (kategori) }\end{array}$ \\
\hline 1. & $\begin{array}{l}\text { Resp } \\
1\end{array}$ & 26 & 36 & 10 & $\begin{array}{c}0.7 \\
1\end{array}$ & $\begin{array}{l}\text { Tinggi } \\
\text { (High-g) }\end{array}$ \\
\hline 2. & $\begin{array}{l}\text { Resp } \\
2\end{array}$ & 27 & 39 & 12 & $\begin{array}{c}0.9 \\
2\end{array}$ & $\begin{array}{l}\text { Tinggi } \\
(\text { High-g) }\end{array}$ \\
\hline 3. & $\begin{array}{l}\text { Resp } \\
3\end{array}$ & 26 & 38 & 12 & $\begin{array}{c}0.8 \\
6 \\
\end{array}$ & $\begin{array}{l}\text { Tinggi } \\
(\text { High-g) }\end{array}$ \\
\hline 4. & $\begin{array}{l}\text { Resp } \\
4\end{array}$ & 26 & 36 & 10 & $\begin{array}{c}0.7 \\
1 \\
\end{array}$ & $\begin{array}{l}\text { Tinggi } \\
(\text { High }-g)\end{array}$ \\
\hline 5. & $\begin{array}{l}\text { Resp } \\
5\end{array}$ & 28 & 39 & 11 & $\begin{array}{c}0.9 \\
2\end{array}$ & $\begin{array}{l}\text { Tinggi } \\
(\text { High }-g)\end{array}$ \\
\hline
\end{tabular}

\begin{tabular}{|c|l|c|c|c|c|l|}
\hline 6. & $\begin{array}{l}\text { Resp } \\
6\end{array}$ & 27 & 39 & 12 & $\begin{array}{c}0.9 \\
2\end{array}$ & $\begin{array}{l}\text { Tinggi } \\
(\text { High }- \text { g })\end{array}$ \\
\hline 7. & $\begin{array}{l}\text { Resp } \\
7\end{array}$ & 26 & 37 & 11 & $\begin{array}{c}0.7 \\
9\end{array}$ & $\begin{array}{l}\text { Tinggi } \\
(\text { High }-g)\end{array}$ \\
\hline 8. & $\begin{array}{l}\text { Resp } \\
8\end{array}$ & 27 & 38 & 11 & $\begin{array}{c}0.8 \\
5\end{array}$ & $\begin{array}{l}\text { Tinggi } \\
(\text { High }-g)\end{array}$ \\
\hline 9. & $\begin{array}{l}\text { Resp } \\
9\end{array}$ & 29 & 39 & 10 & $\begin{array}{c}0.9 \\
1\end{array}$ & $\begin{array}{l}\text { Tinggi } \\
(\text { High }-g)\end{array}$ \\
\hline 10. & $\begin{array}{l}\text { Resp } \\
10\end{array}$ & 25 & 39 & 14 & $\begin{array}{c}0.7 \\
3\end{array}$ & $\begin{array}{l}\text { Tinggi } \\
(\text { High }-g)\end{array}$ \\
\hline
\end{tabular}

Berdasarkan tabel 5 tersebut menunjukkan bahwa semua responden orangtua siswa memperoleh tingkat gain yang kategori Tinggi (High-g) dengan berpedoman pada tabel 6 berikut:

Tabel 6. Pembagian N-gain Skor

\begin{tabular}{|c|c|}
\hline Nilai N-Gain & Kategori \\
\hline $\mathrm{g}>0,7$ & Tinggi \\
\hline $0,3 \leq \mathrm{g} \leq 0,7$ & Sedang \\
\hline $\mathrm{g}<0,3$ & Rendah \\
\hline
\end{tabular}

Hasil pengujian efektifitas Penerapan digital ma-batuter dalam konteks manajemen inovasi pada pengelolaan PAUD yang dikemas dalam digitalisasi sekolah terbukti dapat meningkatkan kualitas pembelajaran anak didik dalam membaca, menulis dan menceritakaan kembali informasi yang diterimanya dibandingkan dengan pengelolaan secara konvensional.

Penilaian orangtua pada penerapan aplikasi digital pada aspek, membaca, menulis, dan menceritakan kembali dipandang oleh sebagaian besar responden sebagai langkah baik dari pihak pengelola PAUD Tamaasa untuk meningkatkan layanan kepada anak didik, hal tersebut didukung hasil perhitungan tingkat efektifitas yang berada pada kategori tinggi (lebih besar 0.7). Hasil temuan ini sejalan dengan peneltian yang dilakukan oleh Raodah dan Ali Subhan (2020: 17) bahwa pelatihan literasi media digital bagi guru PAUD Gugus Kenanga Kecamatan Dukuhseti Kabupaten Pati dapat memberikan dan meningkatkan pengetahuan, pemahaman, pengalaman serta keahlian para guru dalam menggunakan media digital untuk pembelajaran dan administrasi.

\section{PENUTUP}

\section{Kesimpulan}

Hasil penelitian uji-t dan gain score program pendidikan MA-BATUTER dengan aplikasi digital terbukti efektif meningkatkan kemampuan anak didik dalam memahami isi cerita serta dapat menceritakan kembali informasi yang diterimanya dalam rangka melatih sensor intelegensi anak sejak usia dini). 


\section{REFERENSI}

Azwar, Saifuddin. 1999. Reliabilitas dan Validitas. Yogyakarta: Sigma Alpha

Hake dan Richard. R. 1999. Analyzing Change /Gain Scores. Diakses dari laman web tanggal $19 \quad$ Juni 2016 dari:http://www.physics.indiana.edu/ sdi/An alyzingChange-Gain.pdf

Kemdikbud. 2019. Digitalisasi Sekolah Akan Mampu Tingkatkan Kualitas Pembelajaran Siswa. Diakses dari laman web tanggal 24 Juni $2020 \quad$ dari: https://jendela.kemdikbud.go.id/v2/indeks/d ownloadmag/?seo=digitalisasi-sekolahmendayung-generasi-indonesia-maju.

Kreitner, Robert dan Kinicki. 2008. Organizational Behavior. 8th Edition. Boston: McGrawHill.

Mulyasa, 2012. Manajemen PAUD. Bandung: Remaja Rosdakarya.
Raodah \& Ali Subhan. 2020 diakses dari laman web tanggal 2 Juli 2020 dari https://journal.ibrahimy.ac.id/index.php/assi danah/article/view/593/682

Ridho R, Markhamah, Darsinah. 2015. Pengelolaan Pembelajaran Pendidikan Anak Usia Dini (PAUD) di KB “Cerdas" Kecamatan Sukorejo Kabupaten Kendal. Jurnal Penelitian Humaniora 16(2) pp.59-69.

Schumpeter, J.A, 1934. The Theory of Economic Development. Cambridge: Harvard University Press

Sugiyono. 2013. Metode Penelitian Kuantitatif, Kualitatif dan R\&D. Bandung: CV Alfabeta

Suyanto, Slamet. 2005. Dasar-dasar Pendidikan Anak Usia Dini. Hikayat Publishing: Yogyakarta.

Taylor. Frederick Winslow. 2006. The Principles of Scientific Management". Cosimo: New York. 